\title{
Variability in Protein and Esterase Profiles of Botryodiplodia theobromae an Incitant of Longitudinal Splitting of Bark and Wood Disease of Acidlime (Citrus aurantifolia Swingle)
}

\author{
T. Gouri Sankar*, V. Gopi, K. Gopal, Y. Hema Bharathi and Y. Sreenivasulu \\ AICRP on Fruits (Citrus), Citrus Research Station, Dr. Y.S.R. Horticultural University, \\ Tirupati - 517502 (A.P), India \\ *Corresponding author
}

A B S T R A C T

\begin{tabular}{|l|}
\hline Keyw or d s \\
Variability, \\
Biochemical, \\
Protein, \\
Enzyme. \\
\hline Article Info \\
\hline $\begin{array}{l}\text { Accepted: } \\
\text { 15 May 2017 } \\
\text { Available Online: } \\
\text { 10 June 2017 }\end{array}$ \\
\hline \hline
\end{tabular}

Biochemical studies on variability in protein and esterase profiles between twelve isolates of Botryodiplodia theobromae causing Longitudinal Splitting of Bark and Wood Disease (LBWP) on acid lime reveled that isolates LBWP-1 and LBWP-5 exhibited protein pattern with eight banding loci each, LBWP-4 and LBWP-6 with seven banding loci, LBWP-7, LBWP-8 and LBWP-9 with five banding loci and the isolates LBWP-3, LBWP-10, LBWP-11 and LBWP-12 with four banding loci, LBWP-2 exhibited protein pattern with six banding loci. LBWP-1 isolate found to be unique in having one band with $\mathrm{Rm}$ value of 0.83 which was absent in other isolates. Considerable difference among the isolates in banding loci of proteins and considerable variation among the isolates in banding loci of esterase enzyme were noticed. LBWP-5 found to be unique in having two bands with Rm values of 0.18 and 0.32 which were absent in other isolates. Apart from this all the isolates under the study showed significant quantitative differences in the banding profiles for mycelial esterase.

\section{Introduction}

Acid lime (Citrus aurantifolia Swingle) is one of the important citrus fruit grown over an area of $0.90 \mathrm{~m}$ ha and constitutes nearly $20 \%$ of the total citrus production $90.75 \mathrm{mts}$ in India. In India, Andhra Pradesh, Maharashtra, Karnataka, Punjab, and Assam are the leading acid lime growing states. Among the states, A.P occupies the first place both in area and production of limes followed by Maharashtra.

Citrus cultivation in India is facing plethora of production constraints viz., non-availability of sufficient disease free planting material, bud wood transmissible diseases, general neglect, irregular bearing, scarcity of water and poor management practices, cultivation in unsuitable soils. Besides this, citrus species are prone to attack by more than 150 diseases and disorders caused by fungal, viral and few bacterial pathogens right from nursery level to bearing stage resulting in considerable losses of yield and trees. Among the diseases responsible for acid lime decline, the bark and wood splitting malady is the major one affecting both life and production under field conditions. A new disease infecting acidlime 
cause drying of branches, loss of vigour and finally ills the tree with in a span of one year after appearance of the disease. The disease is reported for the first time from AP (Gopal et al., 2005). The pathogen isolated and the pathogenicity on acidlime trees. The malady is seen on almost all the acid lime clones/varieties both on farmer's orchards and on the Research station. It was observed that there was some variation in the symptoms among the different varieties of acidlime. However, there was no difference in pathogenicity. Therefore, to see the variability among the different isolates the present study was undertaken as there was no published report on the pathogen with respect to acidlime.

The use of electrophoresis to analyze different proteins and to distinguish between and to identify cultivars of crop species is one of the latest achievements of biotechnology. Different electrophoretical techniques have been developed for varietal identification. The wide diversity of methods available has caused problem in comparing results between laboratories. This has serious implication, especially as it is becoming an increasingly common occurrence for the grain moving in national and international trade to be monitored for varietal identity and purity and for this, to be carried out, in part at least, by electrophoresis. In addition, many variety testing authorities utilize electrophoresis in certain aspects of their work. It would be extremely useful to be able to use information directly from other organizations and countries.

Moreover isozymes analysis is essential feature of the bio-chemical study. A number of major biological problems such as evaluation of population, transformation, regulation of gene expression and metabolic regulation in differentiated tissues are understood in the light of isozymes. They may arise due to microheterogeneity in proteins, changes in confirmation, genetic mechanisms, etc. Moreover, this experimental technique is available to separate the different isoforms of an enzyme. Polyacrylamide gel electrophoresis is powerful tool for resolving the isozymes to give a zymogram. In the present study variability among the 12 isolate of $B$. theobromae with respect to proteins and esterase was carried and the results are presented in the paper.

\section{Materials and Methods}

The variability among 12 isolates of Botryodiplodia theobromae which were isolated in earlier study were used in the present study to see variability among the isolates in protein and esterase patterns by sodium-dodecyl sulphate polyacrylamide gel electrophoresis (SDS-PAGE) (Laemmlli, 1970) and native PAGE by following the procedure of Sambrook et al., (1989).

\section{Fungal cultures}

Each isolate of the fungus was grown in potato broth for 11 days at $28 \pm 2^{\circ} \mathrm{C}$ and the resultant mycelial mat was used for electrophoretic studies.

\section{Protein and esterase extraction}

For the extraction of enzymes from mycelial mats, the method given by Reddy and Stahman (1972) was used. Mycelial mats were harvested, washed thoroughly with distilled water and homogenized in cold extraction buffer with equal volume in prechilled mortar and pestle. These homogenates were centrifuged at $10,000 \mathrm{rpm}$ for 20 minutes using Eppendorf tubes which served as test solutions.

\section{Polyacrylamide gel electrophoresis}

Polyacrylamide gel electrophoresis (PAGE) was followed for separation of esterase and 
protein fractions. Native PAGE system was used to study esterase and SDS-PAGE system for protein studies.

Preparation of slab gels solutions viz., acrylamide solutions, resolving gel buffer: (1.5 M Tris-HCl, $\mathrm{pH}$ 8.8), stacking gel buffer (0.5 M Tris-HCl, pH 6.8), $10 \%$ sodium dodecyl sulphate, polymerizing agent and electrode buffer.

\section{Preparation of gels}

Gel plates were washed thoroughly with cleaning solution followed by distilled water and dried. Appropriate spacers were placed between the glass plates on sides. Then these glass plates were sealed using a special adhesive tape in order to prevent leakage of gel solution. Resolving gel solution was prepared by mixing the stock solution in appropriate quantities. The solution was poured into the sandwich to a level of $2 \mathrm{~cm}$ from the top. Distilled water was added gently along the wall of the sandwich to form uniform gel surface and allowed for polymerization.

After polymerization, the water on the resolving gel was poured off and wiped off with filter paper. Stacking gel was prepared and overlaid on the resolving gel. The comb was inserted into the stacking gel and allowed to polymerize.

\section{Preparation and loading of samples}

Proteins and isozyme samples were separately prepared in respective sample buffers. The inserted comb was gently removed from the gel after polymerization. The air bubbles, if any, were removed by rinsing with distilled water. The lower and upper chambers of electrophoretic apparatus were filled with electrode buffer. About $70 \mu \mathrm{l}$ of sample was loaded in each well.

\section{Running of gel}

The electrophoretic unit was connected to power pack and a regulated electric power supply of $60 \mathrm{~V}$, slowly raised to $100 \mathrm{~V}$ was supplied for the separation of proteins and isozymes. The electrophoresis was run till the dye front reached the bottom of the gel which took $4 \mathrm{~h}$. Then the power supply was switched off. The gel was carefully dismantled after electrophoresis and incubated in respective staining solution.

\section{Staining of the gels}

The gel was incubated in staining solution for $12 \mathrm{~h}$ and then gel was taken out and properly destained by keeping it in destaining solution. The destaining solution was changed every four hours and destaining was hastened by gently rotating the trays.

\section{Staining solutions for esterase}

After electrophoresis, gel was incubated in staining solution for 30 to 45 minutes and destained with water: methanol: acetic acid: $5: 4: 1$.

The zymograms were prepared indicating the relative mobility of isozyme and protein bands. Photographs were taken immediately after the appearance of bands. Separate runs were made to record the banding pattern of proteins and esterase enzyme. The difference among the isolates of Botryodiplodia theobromae in protein and isozyme pattern was determined by relative mobilities of different protein and isozymes.

Relative mobility $(\mathrm{Rm})$ value $=$

Distance travelled by the protein or isozyme front $(\mathrm{cm})$

Distance travelled by dye front $(\mathrm{cm})$. 


\section{Results and Discussion}

\section{Protein analysis}

The protein banding pattern of 12 isolates of $B$. theobromae is presented in zymogram (Fig. 1). The differences in proteins among the isolates were expressed in terms of relative mobility $(\mathrm{Rm})$ values of bands at different loci.

Among the isolates LBWP-1 and LBWP-5 exhibited protein pattern with eight banding loci each, LBWP-4 and LBWP-6 with seven banding loci, LBWP-7, LBWP-8 and LBWP9 with five banding loci and the isolates LBWP-3, LBWP-10, LBWP-11 and LBWP12 with four banding loci, LBWP-2 exhibited protein pattern with six banding loci.

All the 12 isolates shared two bands with $\mathrm{Rm}$ values 0.06 and 0.2 , five bands with $\mathrm{Rm}$ values 0.68 where as one band was common in LBWP-5 and LBWP-9 shared one band with $\mathrm{Rm}$ value 0.97 . LBWP-1 isolate found to be unique in having one band with $\mathrm{Rm}$ value of 0.83 which was absent in other isolates. The results revealed that there was a considerable difference among the isolates in banding loci of proteins.

\section{Esterase isozyme profile}

The esterase isozyme banding patterns of 12 isolates of $B$. theobromae is presented in the form of zymogram (Fig. 2). The difference in this enzyme among the isolates was expressed interms of relative mobility $(\mathrm{Rm})$ values of bands at different loci.

Considerable variation among the isolates in banding loci of esterase enzyme was noticed. Among the isolates LBWP-7, LBWP-8, LBWP-9, LBWP-10, LBWP-11 and LBWP12 shared one thick band with $\mathrm{Rm}$ value of 0.5 , another band is shared by the isolates
LBWP-2, LBWP-3, LBWP-4, LBWP-5, and LBWP-6 with Rm value of 0.58 .

One thicker band is shared by the isolates LBWP-8, LBWP-9, LBWP-10, LBWP-11 and LBWP-12 with Rm value of 0.25 . Three bands with $\mathrm{Rm}$ values 0.16 exhibited by LBWP-10, LBWP-11, and LBWP-12. LBWP-5 found to be unique in having two bands with Rm values of 0.18 and 0.32 which were absent in other isolates.

Apart from this all the isolates under the study showed significant quantitative differences in the banding profiles for mycelial esterase.

Isozyme and protein patterns can be used as a marker to estimate the amount of variability in a fungal population or species.

They are more neutral than virulence markers since they are not usually exposed to the strong selection pressure of the host. The amount of polymorphism detected by isozyme and protein analysis as a possible key to differentiate fungal pathogens is reviewed.

Polyacrylamide gel electrophoresis gives more quantitative results and produces better resolved banding patterns for isozymes, since both net charge and molecular weight affect the separation of proteins in this system (Rosendahl and Sen, 1992).

The esterase isozyme banding patterns of 12 isolates of $\mathrm{B}$. theobromae showed difference in this enzyme among the isolates and expressed in terms of relative mobility $(\mathrm{Rm})$ values of bands at different loci.

Considerable variation among the isolates in banding loci of esterase enzyme was noticed. Apart from this all the isolates under the study showed significant quantitative differences in the banding profiles for mycelial estarases. 
Fig.1 Zymogram of protein isozyme profile in B. theobromae isolates
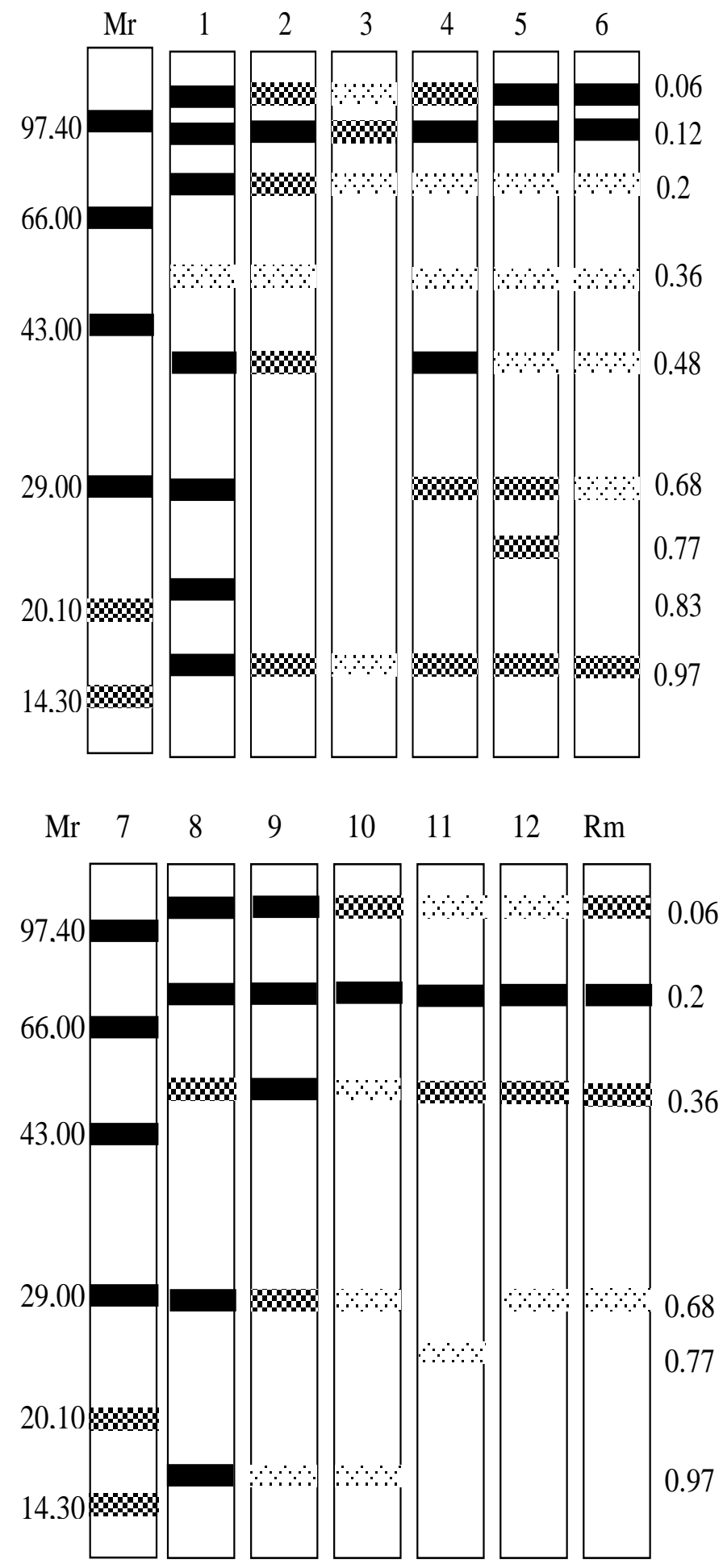
Fig.2 Zymogram of esterase isozyme profile in B. theobromae isolates


1 to 12 are isolates of $B$. theobromae isolates obtained longitudinal splitting of bark and wood disease infected acidlime trees (LBWSP-1 to LBWSP -12); Rm - Relative mobility

Isozyme variability among isolates of Assochyta rabiei was studied by Uma Devi et al., (2001) using native PAGE. Esterase, malate dehydrogenase and acid phosphatase gave polymorphic banding patterns whereas peroxidase; alkaline phosphatase and glutamate dehydrogenase resulted in monomorphic banding pattern. Identical protein profiles for all the isolates with respect to major bands and differences in the minor bands were observed in SDS-PAGE for total proteins.
Caccardi et al., (1998) partially characterized the protein associated with citrus blight (disease of unknown cause). The $12 \mathrm{kD}$ protein designated $\mathrm{p} \mathrm{12}$, was diagnostic of citrus blight and was present in leaves and xylem fluid of roots and stems of citrus blight affected trees. The protein and upto six other citrus blight specific proteins were readily detected by SDS-PAGE from xylem fluid of citrus blight affected trees. Clare (1963) used starch gel electrophoresis of proteins as an aid in identifying different species of Pythium 
and two other Ascomycetous fungi. Isozyme analysis on PAGE provides a well-established and efficient tool for revealing genetic variability in fungal population (Micales et $a l .$, 1986). Fifty enzymes and protein strains of Uromyces appendiculatus were screened in the horizontal gel electrophoresis system by Linde et al., (1990). Chen et al., (1991) compared soluble proteins and isozymes from seven Pythium species by SDS-PAGE and starch gel, respectively. Similarities in soluble protein banding patterns and isoenzyme phenotypes were detected for morphologically distinct species. Sudhakar (1996) reported that electrophoretic studies of proteins and esterases of $R$. solani expressed a narrow genetic distances between the isolates obtained from geographically nearer locations and vice versa. Isozyme analysis provides an effective means of identifying Pythium spp. that do not readily produce oospores in culture (Barr et al., 1997).

\section{References}

Barr, D.J.S., Warwick, S.I. and Desaulniers, N.L. 1997. Isozyme variation in heterothallic species and related asexual isolates of Pythium. Canadian Journal of Botany, 75: 1927-1935.

Ceccardi, T.L., Barthe, G.A and Derrick, K.S. 1998. A novel protein associated with citrus blight has sequence similarities to expansion. Plant Molecular Biology, 38: 775-783.

Chen, W., Hoy, J.W. and Schneider, R.W. 1991. Comparison of soluble proteins and isozymes for seven Pythium species and applications of the biochemical data of
Pythium systematics. Mycological Research, 95: 548-555.

Clare, B.G. 1963. Starch gel electrophoresis as an aid in identifying fungi. Nature, 100: 803804.

Gopal, K., Suresh, M., Gopi, V., Sreenivasulu, Y., Khayum Ahemmed, S. and Sivakumar, N. 2005. First Report on Etiology and Management of Bark and Wood Splitting Disease in Acidlime from Andhra Pradesh. Paper presented in IInd Global Conference, organized by Indian Society of Mycology and Plant Pathology, MPUAT, Udaipur. 25th to 29th November

Laemmli, U.K. 1970. Cleavage of strucutural proteins during the assembly of the head of bacteriophage T4. Nature, 227: 680-685.

Linde, D.C., Groth, J.V. and Roelfs, A. P. 1990. Comparison of isozyme and virulence diversity patterns in the bean rust fungus Uromyces appendiculatus. Phytopathology, 80: 141-147.

Micales, J.A., Bonde, M.R. and Peterson, G.L. 1986. The use of isozyme analysis in fungal taxonomy and genetics. Mycotaxon, 27: 405-449.

Reddy, M.N. and Stakman, M.A. 1972. Isozyme patterns of Fusarium species and their significance in taxonomy. Phytopathology, 74: 115-125.

Rosendhal, S. and Sen, R. 1992. Isozyme analysis of Mycorrhizal fungi and their mycorrhiza. Methods in Microbiology, 24: 1691-94.

Sambrook, J., Fritsch, E.F. and Maniatis, T. 1989. Molecular cloning: A laboratory manual. Cold Spring Harbor Laboratory, New York.

Sudhakar, R. 1996. Variability in Rhizoctonia solani Kuhn and management of sheath blight of rice. Ph.D. Thesis, APAU, Hyderabad, India, $211 \mathrm{pp.}$

Uma Devi, G. 2001. Isozyme variability among isolates of Ascochyta rabiei. Indian Phytopathology, 54:16-22.

\section{How to cite this article:}

Gouri Sankar, T., V. Gopi, K. Gopal, Y. Hema Bharathi and Sreenivasulu, Y. 2017. Variability in Protein and Esterase Profiles of Botryodiplodia theobromae an Incitant of Longitudinal Splitting of Bark and Wood Disease of Acidlime (Citrus aurantifolia Swingle). Int.J.Curr.Microbiol.App.Sci. 6(6): 3220-3226. doi: https://doi.org/10.20546/ijcmas.2017.606.379 